\title{
Modern aspects of ensuring the security of the agro-industrial complex
}

\author{
Larisa Bryantseva*, Natalia Shishkina, and Tatiana Sabetova \\ Voronezh State Agrarian University named after Emperor Peter the Great, 394087, Michurina, 1, \\ Voronezh, Russia
}

\begin{abstract}
The article substantiates the urgent need for the formation of import-substituting clusters in the agro-industrial complex to ensure food security. In modern reality, carrying out business activities, agro-industrial organizations are already using the advantages of integration to a certain extent, but at the same time, the key interests and guidelines of allied participants in entrepreneurial activities are insufficiently balanced. The authors have identified the methodological features of the formation of the subject of integration (agri-food polycluster formation), using the cluster tools of intersectoral reengineering. The basis for the introduction of the subjects of integration - allied participants in entrepreneurial activity - was their initial assessment and analysis of the factors and conditions of business activity, where the negative results of import substitution, which is an effective threat to food security, can be traced as much as possible. Evaluation of the target pairing through the integration of related business participants allows one to quantitatively assess the predominance of the target points of integration subjects - related business participants using information at the macro and micro levels.
\end{abstract}

\section{Introduction}

At present, the safety of the industry related to food production should be considered as an attributive part of the national food security, since there is no doubt that the solution of other strategic tasks of the development of the agro-industrial complex is problematic without domestic food production.

Thus, each entrepreneurial structure as a key business goal puts forward the achievement of a stably balanced and most effective business development today, as well as obtaining significant opportunities in the future.

In this regard, organizations of the agro-industrial complex are experiencing difficulties that threaten them with a decrease in the performance indicators of their business activities, which may arise due to the low security of the company's business units responsible for personnel, raw materials, technologies and technical potential from the aggressive financial and economic policy of the state, which affects both external and internal business relations of entrepreneurial structures.

\footnotetext{
*Corresponding author: blv2466@mail.ru
} 


\section{Materials and methods}

Analysis of factorial features and variable changes in business of allied participants in entrepreneurial activity in the agro-industrial sector of the economy suggests the need to create import-substituting subjects of integration in the agro-industrial complex to ensure food security, since Russian agriculture depends not so much on imports of food products as on resource potential and technological components necessary for food and auxiliary industries $[2 ; 4]$.

The ultimate goal of business relations of the subjects of the agro-industrial complex is to ensure industrial safety, the optimal level of which automatically ensures the food security of the country.

The level of industrial safety is formed under the influence of factors of internal (underutilized opportunities) and external (diplomatic component) nature, food safety - by the level of industrial safety and the import of food products of a specific type. The developed methodology "Algorithm for indicating business relations in the agro-industrial complex" (using the example of sugar beet production) allows at each separately taken stage of the production business cycle: to determine the degree of underutilization of opportunities; to judge the optimality of business relationships; to determine the degree of influence of threats of non-optimal business relations on the level of industrial safety.

The value of the industrial safety coefficient corresponds to the lowest level of all indicators of business relations. The algorithm of the developed methodology for indicating business relations is presented in Table 1 .

Table 1. Algorithm for indicating business relations in the agro-industrial complex (based on the example of sugar beet production).

\begin{tabular}{|c|c|c|}
\hline Indicators & Potential values of the indicators & Actual values of the indicators \\
\hline \multirow[t]{2}{*}{$I_{1}$} & \multirow{2}{*}{$\begin{array}{c}\frac{M_{\text {seeds.f }} *\left(P_{\text {seeds }} * B_{\text {seeds }}\right)_{\text {norm }}}{V_{\text {seeds are necessary }}} \\
* 100 \%\end{array}$} & $V_{\text {domestic seeds }} *\left(\frac{U}{P} * B_{\text {sugar }}\right)_{f}$ \\
\hline & & $\begin{array}{c}V_{\text {seeds are necessary }} *\left(\frac{Y}{P} * B_{\text {sugar }}\right)_{\text {norm }} \\
* 100 \%\end{array}$ \\
\hline \multirow[t]{2}{*}{$I_{2}$} & \multirow[t]{2}{*}{$\operatorname{MIN}\left(K_{o b . f}, K_{\text {total area } \mathrm{f}}\right) * 100 \%$} & $\left(V_{\text {domestic beetroot }} * B_{\text {sugar }}\right)_{f} * 100 \%$ \\
\hline & & $V_{\text {beets are necessary }} * B_{\text {sugar }}$ \\
\hline \multirow[t]{2}{*}{$I_{3}$} & $M_{\text {sugar.f }} *\left(P_{\text {sugar }} * B_{\text {sugar }}\right)_{\text {norm }}$ & $V_{\text {sugar beet. } f} * 100 \%$ \\
\hline & $\begin{array}{l}V_{\text {sugar is necessary }} \\
* 100 \%\end{array}$ & $V_{\text {sugar is necessary }}$ \\
\hline Kind & $\stackrel{3}{M I N}{ }_{1}{ }_{n i}$ & $\stackrel{3}{M I N} U_{\phi_{i}}$ \\
\hline
\end{tabular}

$\mathrm{I}_{1}, \mathrm{I}_{2}, \mathrm{I}_{3}$ - industrial security indicators;

$\mathrm{K}_{\text {ind }}$ - industrial security index, units;

$M_{\text {seeds.f }}, M_{\text {sugar.f }}$ - actual capacity of seed and sugar plants of the Russian Federation, t/day;

$K_{o b . f}, K_{\text {total area }}$ - use factor of beet-harvesting machinery, crop acreage, units;

$P_{\text {seeds }}, P_{\text {sugar }}$ - duration of the productive season for seed and sugar plants, days;

$B_{\text {seeds }}, B_{\text {sugar }}$ - finished product output of seed and sugar plants, $\%$; 
$V_{\text {seeds are necessary }}$ - required amount of sugar for provision of the physiological need of the population, ths tons;

$V_{\text {seeds are necessary }}, V_{\text {beets are necessary }}$ - required amount of seed and sugar beet, taking into account

$V_{\text {sugar is necessary }}$, tons, ths tons;

$V_{\text {domestic seeds } f}$ - sugar beet seeds amount produced using domestic components only, tons;

$\mathrm{U}$ - sugar beet yield per 1 hectare, т/га;

$\mathrm{P}$ - seed material consumption per 1 hectare, $\mathrm{kg}$;

$P_{\text {beets. } n}$ - sugar beet crop areas, ths ha;

$P_{\text {domestic beetroot }}$ - sugar beet crop areas planted with the seeds of Russian selection, ths ha;

$V_{\text {sugar beet }}$ - sugar produced from sugar beet, ths tons.

The use of such an approach in determining the required amount of sugar to meet the needs of the country's population makes it possible to judge the appropriateness of certain areas of development of business relations in the sugar beet complex.

Actual research of our time, analyzing the reasons and factors for the safe conduct of business by processing entrepreneurial structures, including sugar production, differ in species diversity: researching the nature of economic threats, researching the nature of industrial threats and researching the nature of food threats. At the same time, the greatest interest is shown in equilibrium (balanced) development management in organizations of the agro-industrial complex using cluster tools.

Potential threats to balanced business relations and the need to eliminate the dangers of their transformation into a negative synergistic effect for the company's business activities are the reason why it is necessary to find out the danger of this socio-economic phenomenon, on the one hand, and find out ways to level them, on the other hand.

At the same time, we designate two foundations of economic activity, leading to the threat of falling competitive business development:

(i) industrial and production aspects of business activities of entrepreneurial structures;

(ii) logistic relationships of interdependent entrepreneurial business units.

Analyzing the modern aspects of increasing the level of safety in the activities of organizations in the agro-industrial complex, it is necessary, first, to focus on issues of state support for such enterprises. At the same time, one should not underestimate the importance of documentation support for conducting effective business activities, including by organizations of sugar beet production (standards, regulations) that allow the agricultural sector of the economy to ensure the country's food security.

\section{Discussion of results}

In modern reality, the management of organizations increasingly uses such management methods that are associated with the benefits of integrating adjacent business participants [7]. Such integration, which makes it possible to reduce the threat to food security, creates the following advantages for its participants: concentration of subjects on a territorial basis; competition within the cluster; stability of economic and social ties; polycentricity; unidirectional co-development of the subjects of integration; positive synergy effect. Taking into account the above aspects of allied participants in entrepreneurial activity, we propose 
to use the methodological features of the formation of the subject of integration (agro-food polycluster formation), using the cluster tools of inter-sectoral reengineering (Table 2).

The basis for the creation of an APF is an expert factorial analysis of the functioning of allied participants in entrepreneurial activity; the negative consequences of import substitution that threaten the food security of the country are clearly visible [6].

Table 2. Processes of the implementation of the cross-sectoral reengineering project during the formation of the APF.

\begin{tabular}{|c|c|c|c|c|}
\hline \multicolumn{2}{|c|}{$\begin{array}{c}\text { Inter-sectoral } \\
\text { reengineering algorithm }\end{array}$} & \multicolumn{2}{|c|}{$\begin{array}{c}\text { Processes of creating an agro-food poly- } \\
\text { cluster formation }\end{array}$} & \multirow[t]{2}{*}{ Results } \\
\hline Stage & Name & Stage & Stage's essential contents & \\
\hline \multirow[t]{2}{*}{1} & \multirow[t]{2}{*}{$\begin{array}{l}\text { Creating the } \\
\text { future image }\end{array}$} & 1.1 & $\begin{array}{l}\text { Balancing the key interests of } \\
\text { regional business participants: } \\
\text { the state; cluster; region; } \\
\text { organizations, etc. }\end{array}$ & \multirow[t]{2}{*}{$\begin{array}{l}\text { Identification of key } \\
\text { landmarks of the cluster }\end{array}$} \\
\hline & & 1.2 & $\begin{array}{l}\text { Cluster development strategy } \\
\text { development: focusing on } \\
\text { internal needs; export } \\
\text { orientation; orientation towards } \\
\text { import substitution }\end{array}$ & \\
\hline \multirow[t]{4}{*}{2} & \multirow[t]{4}{*}{$\begin{array}{l}\text { Reverse } \\
\text { reengineering }\end{array}$} & 2.1 & $\begin{array}{l}\text { Assessment of the potential of } \\
\text { the region }\end{array}$ & $\begin{array}{l}\text { Determination of the } \\
\text { contribution of the cluster } \\
\text { to ensuring industrial and } \\
\text { production security }\end{array}$ \\
\hline & & 2.2 & $\begin{array}{l}\text { Development of a motivation } \\
\text { system for cluster subjects }\end{array}$ & $\begin{array}{l}\text { Regional (federal) program } \\
\text { of support for the subjects } \\
\text { of cluster formations }\end{array}$ \\
\hline & & 2.3 & $\begin{array}{l}\text { Identification of existing } \\
\text { external relations among the } \\
\text { subjects of the cluster }\end{array}$ & P-model \\
\hline & & 2.4 & $\begin{array}{l}\text { Identification of internal } \\
\text { connections between the } \\
\text { subjects of the cluster and the } \\
\text { subjects of other clusters }\end{array}$ & O-model \\
\hline \multirow[t]{4}{*}{3} & \multirow[t]{4}{*}{$\begin{array}{l}\text { Direct } \\
\text { reengineering }\end{array}$} & 3.1 & $\begin{array}{l}\text { Identification of opportunities } \\
\text { for self-development of the } \\
\text { cluster for a long-term period }\end{array}$ & P-model \\
\hline & & 3.2 & $\begin{array}{l}\text { Identification of opportunities } \\
\text { for self-development of } \\
\text { competing clusters for a long- } \\
\text { term period }\end{array}$ & Virtual O-model \\
\hline & & 3.3 & $\begin{array}{l}\text { Revealing the causes, factors and } \\
\text { conditions of intra-cluster and } \\
\text { inter-cluster business relations }\end{array}$ & P-model \\
\hline & & 3.4 & $\begin{array}{l}\text { Adjustment of goals, strategy, } \\
\text { relationships, etc. }\end{array}$ & Actual O-model \\
\hline
\end{tabular}

We have considered the fundamental aspects and significant stages of the APF project implementation using the example of sugar beet production, since this industrial-production subsystem of the agro-industrial complex is currently a set of organizational and economic relations that most significantly reduce the country's food security.

Assessment of the conditions and trends in the development of the main production subsystems of the Russian agro-industrial complex makes it possible to state the need for an import-substituting cluster orientation to ensure industrial and production safety, since the intervention of imported products is due to the supply of not so much food products as 
resource and technological components that are constantly required by food production, as well as auxiliary and providing types of economic activity.

The conditions and factors for ensuring the conduct of a safe business by organizations of the agro-industrial complex should be assessed, in our opinion, taking into account the scale of their occurrence and the close relationship between the levels of safety of various types. From our point of view, the basis (basic platform) is industrial safety, the provision of which is possible through the highly efficient use of the resources and production capacities of organizations at the disposal of entrepreneurial structures, taking into account the invariably significant value of economic security. Neglect of underutilized opportunities and lost benefits by entrepreneurial agro-industrial structures will permanently lead to their loss of organizational and economic independence and stagnation of economic development at the macroeconomic level.

Applying the methodological features of the formation of the subject of integration for entrepreneurial agro-industrial structures, we recommend using the matrix of target pairing of subjects of integration-adjacent participants in entrepreneurial activity: the state, an integrated formation, processing organizations, agricultural organizations, research institutions, educational institutions, and other organizations. The essence of the matrix reflects the content of the dual advantages of such integrated formations: the activation of a specific target of a group of organizations-subjects of integration and the accumulation of professional knowledge, which ultimately helps to protect the advantages of competition of the agro-industrial structure at the inter-cluster level.

The methodological approach to the formation of a cluster is demonstrated along the diagonal of the matrix structure: firstly, the existing intra-cluster competition activates the vector of self-development and conjugation of the key tasks of the cluster; secondly, intercluster competition contributes to the formation of the vector of target pairing of the subjects of integration - adjacent participants in entrepreneurial activity [5].

The authors revealed that in the formation of such a subject of integration as APF (agroindustrial polycluster formation), there are all the necessary conditions for its integral selfdevelopment and the implementation of effective rivalry. As a result, at this stage it becomes realistic to determine the possible subjects of integration, capable of ensuring compliance with the principle of polycentricity of adjacent business participants, as well as quantifying the competitive advantages of the cluster at the inter-cluster level.

For the entrepreneurial structures of the agro-industrial complex, food security is of the greatest importance, the assessment of which, in our opinion, is advisable to be carried out in structural subordination (hierarchically), observing the sequence: analysis of the possibilities of ensuring the subject of integration of food security; analysis of the contribution of the subject of integration to ensuring industrial, production and food security. Such an approach, from our point of view, contributes to the conjugation of the targets of allied participants in entrepreneurial activity, which, as a result, will have a positive effect on the general state of the Russian agro-industrial complex [1;3].

On a planetary scale, it is generally accepted that state food security is ensured while maintaining the internal volume of consumption by $80 \%$ of its own food. About $20 \%$ is replenished by the state through food imports [8]. This proportion provides a certain state independence from the import of strategic food products. The situation in Russia is such that food security has given way to industrial security in the hierarchical structure of security, i.e. at present, the importance of the latter is higher. In fact, sugar produced from raw sugar is domestic, and when it is exported by other countries, importers are perceived and accounted for as Russian sugar. A paradoxical situation arises: imported white sugar, with its full consumption, would make up 5\% of the total sugar consumption in Russia. Consequently, in fact, Russia exceeds the threshold of food independence by $15 \%$, but the domestic sugar 
industry, on average, by $75 \%$ depends on imported raw materials and other components necessary for sugar production.

The logical connection, therefore, between the industrial, food and economic security of the country is breached. Food security, it turns out, falls out of this chain in a certain way, since it does not reflect the actual state of affairs in the sugar industry and the country as a whole.

\section{Conclusion}

Summarizing the above, we note that in the course of analyzing the essence of management as a system, considering security issues, including food security, we based on the following provisions. Firstly, the target of allied business participants is to obtain maximum economic benefits in the course of carrying out business activities, and secondly, business structures are obliged to try to make only economically justified costs and expenses that allow them to obtain optimal economic benefits, or to reduce the estimated costs in the future.

At the same time, the economic state of the Russian Federation can be considered safe if at least five conditions are met: living conditions and personal development that are acceptable for the majority of the population; stable socio-economic situation; military and political stability of society; the integrity of the state; the ability to resist the influence of internal and external threats.

One of the most significant elements of the government strategy, in our opinion, is the identification and monitoring of factors that reduce the stability of the socio-economic system of the state and the formation of economic policy that eliminate or mitigate their impact, the characteristics of threats to economic protection from security threats, the localization of which should be the first turn is focused on the activities of federal government bodies, focuses on the deformation of the structure of the Russian economy. Including due to such factors as the low competitiveness of products, the curtailment of production in vital industries, the conquest of the Russian domestic market by foreign firms for many types of consumer goods, etc.

\section{References}

1. A.V. Agibalov, L.A. Zaporozhtseva, V.B. Malitskaya, Z.P. Medelyaeva, Yu.V. Tkacheva, Agricultural companies as a russian regions' economic driver, 35th International Business Information Management Association Conference (IBIMA). Proceedings of the 35th International Business Information Management Association Conference (IBIMA) 1623 (2020)

2. A.I. Altukhov, Food Security of the Russian Federation: Assessment Methodology Issues Economics of Agricultural and Processing Enterprises, 7, 2 (2016)

3. L.A. Zaporoztseva, The problem of reproduction in agriculture, 36th International Business Information Management Association Conference (IBIMA). Proceedings of the 36th International Business Information Management Association Conference (IBIMA) 1808 (2020)

4. V.N. Ivanov, S.N. Seregin, Agro-industrial policy of the EAEU: ensuring food security Suga, 10, 14 (2015)

5. L.V. Bryantseva, Assessment of the potential of ensuring industrial and production safety on the basis of creation of polycluster formations in the aic Bulletin of the Saratov State Agrarian University. N.I. Vavilov., 10, 70 (2009)

6. E.A. Vysotskaya, L.V. Briantseva, Coherence degree characteristic of production, industrial and food security of agro-industrial complex subsystems IOP Conference 
Series: Earth and Environmental Science. 6th International Conference on Agriproducts Processing and Farming. 012102 (2020)

7. L.O. Makarevich, A.V. Ulezko, The mechanism of integrational interactions of economic subjects: methodological aspects, The Challenge of Sustainability in Agricultural Systems. Cep. "Lecture Notes in Networks and Systems" Heidelberg 23 (2021)

8. I.G. Ushachev, Import substitution in the agro-industrial complex of Russia: trends, problems, ways of development, Economy of agricultural and processing enterprises, 1, 2 (2016) 